\title{
The Evaluation of Management Standards on Accreditation Results of PAUD Institutions in 2017 Year (Study of Accreditation Results Documents in BAP PAUD and PNF West Kalimantan)
}

\author{
Hamka $^{1)}$, Wahyudi $^{2)}$, M Chiar ${ }^{3)}$ \\ ${ }^{1)}$ Universitas Tanjungpura, Pontianak, Indonesia \\ E-mail:hamkaptk@gmail.com \\ ${ }^{2)}$ Universitas Tanjungpura, Pontianak, Indonesia \\ E-mail: wyudi_fkip@yahoo.com \\ ${ }^{3)}$ Universitas Tanjungpura, Pontianak, Indonesia \\ E-mail: chiarfkip@gmail.com
}

\begin{abstract}
The purpose of this study was to determine the results of accreditation on the standard aspects of PAUD management. This research method uses a documentary study method with a qualitative approach. This type of research in this study is a descriptive case study research. Based on the evaluation recapitulation of all aspects of the management standard that PAUD institutions on average do not yet have a work inspection and assessment document therefore it is a problem that the low achievement period of 8 standards in PAUD units that apply for accreditation in 2017 due to the low 2 aspects PAUD institutions have not yet been launched.
\end{abstract}

Keywords: Evaluation; Management Standards; Accreditation

\section{INTRODUCTION}

Accreditation is an assessment of the feasibility of an education unit/program, both Formal, Non-formal and Informal. Accreditation is carried out by the National Accreditation Organizing Body which oversees the quality of education programs consisting of the National Higher Education Accreditation Board (BAN-PT), National School / Madrasah Accreditation Board (BAN-S / M) and the National Accreditation for Early Childhood Education and Education Nonformal (BAN - PAUD and PNF). Whereas PAUD Accreditation is an assessment of program feasibility in PAUD programs and units based on predetermined criteria which in this case is the National Education Standards (SNP).

Government regulation number 19 of 2005 as where there has been a second change, namely number 13 of 2015 concerning national education standards, in Article 1 paragraph 32 states "National Accreditation Board for Early Childhood Education and Non-Formal Education, hereinafter referred to as PAUD PAAN and PNF is evaluation bodies independent which establish the feasibility of programs and/or units of early childhood education and non-formal education by referring to the National Education Standards. Then for the implementation of BAN PAUD and PNF accreditation, it has also been regulated in the national education minister's regulation number 52 of 2015 concerning PAUD and PNF National Accreditation Bodies, which functions of PAUD and PNF BAN are independent evaluation bodies that determine program eligibility and/or age education unit early and nonformal education with reference to the National Education Standards. Institutionally PAUD and PNF BAN have an organizational structure starting from the district level, namely the Working Group of PAUD and PNF Accreditation, the provincial level, namely the Provincial Accreditation Board for PAUD and PNF and at the central level, namely the PAUD and PNF National Accreditation Bodies. Provincial Accreditation Board (BAP) PAUD and PNF are existing bodies at the provincial level as implementing 
agencies for the accreditation process for PAUD and PNF programs and units. The function of BAP PAUD and PNF is to implement policies that have been prepared by BAN PAUD and PNF that are at the central level so that BAP PAUD and PNF do not have the authority to make decisions on accreditation assessments. Therefore to maintain the quality of early childhood education quality, the program and its units need to be accredited.

Accreditation assessment is inseparable from eight national education standards in which each level of education has its standard of regulation, as in the eight National Standards for Early Childhood Education (PAUD) regulated in Minister of Education and Culture number 137 of 2014 concerning national education standards early childhood (PAUD). The eight standards are (1) the standard level of achievement of child development, (2) content standards, (3) process standards, (4) standards of educators and education personnel, (5) standards of facilities and infrastructure, (6) management standards, (7) financing standards and (8) assessment standards. Of the eight standards that have quite a lot of aspects in their implementation are the 6th standard, which is management standards.

The PAUD management standard is an implementation that refers to the standards of content, processes, educators and education personnel, facilities and infrastructure, and financing. In education and culture minister's regulation number 137 concerning nationally early childhood education precisely Article 34 which reads: Standards for Management of Childhood Education include (1) program planning, (2) organizing, (3) implementation of work plans and (4) supervision. Management Standards PAUD programs are very influential on the quality of early childhood education because in its implementation PAUD program management is the main thing in making education services at the early childhood level.

To achieve quality PAUD, standard management is required in accordance with national education minister's regulation number 137 concerning PAUD standards described by the Paud Accreditation Board and PNF in the program and unit accreditation instruments which have subsequently been formulated into 14 indicators that should be implemented by the Paud program and units. So that if the Paud program implements these 14 indicators, the implementation of the PAUD program management will be maximal and quality. There are still many Paud institutions that have not been able to implement the standards of these indicators so that there are still many PAUD institutions in West Kalimantan that still get $\mathrm{C}$ accreditation scores.

Evaluation of a program or system needs to be done as stated by Stufflebeam, (2014: 3) that evaluation is a process to provide an assessment in the ability of reliability, effectiveness, cost-effectiveness, efficiency, security, ease of use, and truth reinforced by Wirawan, (2011) that evaluation is a systematic method for collecting, analyzing, and using information to answer basic questions about the program. While the purpose of the evaluation according to Wirawaan (2011, in general, is to achieve various objectives according to the object being evaluated.

Specifically, the evaluation objectives according to interviewees are: (1) measuring the influence of the program on the community, (2) assessing whether the program has been implemented in accordance with the plan, (3) measuring whether the program is in accordance with the standards, (4) program evaluation can be identified where the program dimensions which way and which program dimensions are not working, (5) program staff development, (6) fulfilling the provisions of the law, (7) program accreditation, (8) measuring costeffectiveness and costs, (9) making decisions about the program, (10) accountability, (11) providing feedback to program leaders and staff, (12) strengthening political positions, and (13) developing theories of evaluation or evaluation research. Of the several evaluation functions mentioned above, one of the functions of the evaluation itself is accreditation. As the function of accreditation is to assess the feasibility of an Education unit/program, in this case, is Early Childhood Education.

Based on the book that has been compiled by BAP PAUD and PNF West Kalimantan in 2016 and 2017 with the title "profile of Program accreditation and PAUD and PNF West Kalimantan Unit" that the number of PAUD accreditation in West Kalimantan in 2017 is as many as 276 institutions consisting of Playgroup groups are 152 institutions, kindergartens are 109 institutions, Child Care are 3 institutions, Similar PAUD units are 2 institutions and Raudhatul Atfal as many as 10 institutions. The results of PAUD accreditation in 2017 are still many institutions that still get $\mathrm{C}$ (Enough) which is 125 PAUD institutions from 276 accredited institutions. If it is made in percentage form, $\mathrm{C}$ accreditation results reach $54.7 \%$, so there are still more than half of accredited institutions that get $\mathrm{C}$ (enough) in West Kalimantan in 2017.

In the initial observations that have been made by researchers conducted a more in-depth analysis of the results of PAUD accreditation in the West Kalimantan BUD PAUD and PNF namely by discussing aspects of assessment achievement based on 8 National Standards of PAUD Education. The reason researchers analyzed because the accreditation assessment refers to 8 National Education Standards (SNP) so that it will make it easier for researchers to find and uncover the data to be studied. Observations were made by requesting accreditation assessment data from the BAP PAUD and PNF secretariat and 
through limited interviews with members of the West Kalimantan BUD PAUD and PNF.

Percentage of PAUD accreditation assessment results are shown which, when viewed based on SNP aspects, in the last two years the results of accreditation assessment have decreased, namely in standard 3, standard 4, standard 5, standard 6, standard 7 and standard 8. So that if flat leveling down to reach $12 \%$. It makes the researcher more interested in examining it further so that the researcher wants to go to one of the standards that gets the lowest percentage. The aim is to be more accurate in analyzing accreditation data and documents, both from the results of the assessment and the documents that the institution has. Based on the figure it can be seen that the lowest percentage of the eight national standards of PAUD education is on management standards or standards 6 . Therefore researchers are interested in reviewing and seeking information in depth to research the results of 2017 PAUD accreditation, especially in PAUD management standards.

\section{RESEARCH METHOD}

This research method uses documentary study method with a descriptive qualitative approach. The documentary study was chosen because researchers wanted to examine in depth the PAUD accreditation documents, while the qualitative approach was chosen because the researchers wanted to describe the findings of the document findings on the results of the accreditation assessment on PAUD management standards.

This research includes qualitative research because document studies are part of qualitative research. The implementation of qualitative research methods is not limited to the collection and compilation of data but includes analysis and interpretation of the data, other than that all that is collected allows being key to what is examined and then drawn a conclusion. This type of research in this study is a descriptive case study research. In this study, researchers collected data/documents from accreditation assessment reports from PAUD assessors in the Accreditation Board of West Kalimantan Province and attachment documents (forms) accreditation. The researchers then analyzed the questions in the accreditation instrument for the analysis of the parts that were not answered or implemented by PAUD institutions.

\section{A. Result}

\section{RESULT AND DISCUSSION}

The research findings conducted by researchers are as follows:

1. Evaluation of Management Standards in Planning Aspects
Evaluations conducted on planning aspects consist of 6 indicators in accordance with the standards in PAUD accreditation, namely:

a. Vision

In the visual indicator to achieve a standard vision that is owned by PAUD institutions must have five elements: (1) Short Solid, (2) Realistic, (3) Visionary, (4) Anticipatory, and (5) Measured.

The vision formulation that is owned by PAUD institutions in West Kalimantan, the highest percentage of the percentage is in the visionary sub-indicator, which is $80 \%$. Visionary means in accordance with the times. While the lowest percentage of the acquisition is in the measured sub-indicators which are $47 \%$, it means that it can be implemented.

b. Mission

In the mission indicator, to achieve a standard mission that is owned by PAUD institutions must have four elements, namely: (1) Relevant, (2) Realistic, (3) Consistent, and (4) Measured. The mission formulation of PAUD institutions in West Kalimantan whose highest percentage is in the relevant sub-indicators, which is $76 \%$, relevant in accordance with the institution's vision, while the lowest acquisition of the process is in the measured sub-indicators which are $57 \%$ measured meaning that it can be implemented by institution in line with vision.

c. Aim

In the goal indicator, to achieve the standard objectives of PAUD institutions must have four elements, namely: (1) Consistent with Vision, (2) Consistent with Mission, (3) Realistic, and (4) Measured. The aim of PAUD institutions in West Kalimantan with the highest percentage of value is in the realistic sub-indicators, which is $75 \%$. While the lowest acquisition of the process is in the sub-indicators consistent with the mission that is $57 \%$.

d. Socialization of Vision and Mission Objectives

To achieve the socialization of the vision, mission and goals that are standard possessed by PAUD institutions must have four elements, namely: (1) print media, (2) meetings with parents, (3) institutional work meetings, (4) online media and (5) posted on the bulletin board. The socialization of the vision, mission, and objectives of PAUD institutions in West Kalimantan, the highest percentage of which was in the sub-indicator posted on the bulletin board, which was $59 \%$. While the lowest acquisition of the process is in the print media sub-indicator which is $19 \%$.

e. The Annual Work Plan

To achieve a standard annual work plan owned by PAUD institutions must have five 
elements, namely: (1) Objectives, (2) Targets, (3) Policy, (4) Programs / Activities and (5) Financing. The highest formulation of the mission of PAUD institutions in West Kalimantan is the program/activity sub-indicator, which is $76 \%$. While the lowest acquisition of the process is in the policy sub-indicator, which is $49 \%$.

\section{f. Five-Year Work Plan}

To achieve a standard five-year work plan that is owned by PAUD institutions must have five elements, namely: (1) Objectives, (2) Targets, (3) Policies, (4) Programs / Activities and (5) Financing. The five-year work plan owned by PAUD institutions in West Kalimantan with the highest percentage of their presentations is in the program/activity sub-indicator, which is $71 \%$. While the lowest acquisition of the process is in the policy sub-indicator, which is $49 \%$.

From all the results of the research on the sub-indicators of planning aspects, the researcher formulates these results in the form of percentages grouped in scores according to document analysis techniques. The results of document analysis have obtained the following results:

\section{Table I}

Recapitulation of Documents Accreditation Evaluation on Aspects of Standard Planning for PAUD Management in West Kalimantan 2017

\begin{tabular}{llccc}
\hline No & \multicolumn{1}{c}{ Indicator } & $\begin{array}{c}\text { Document } \\
\text { Availability } \\
(\%)\end{array}$ & $\begin{array}{c}\text { Average } \\
\text { Assessment } \\
\text { Results }\end{array}$ & $\begin{array}{c}\text { Asssessmen } \\
\text { Category }\end{array}$ \\
\hline 1 & Vision & 100 & 3,6 & Good \\
\hline 2 & Mission & 100 & 3,4 & Good \\
\hline 3 & Purpose & 100 & 3 & Good \\
\hline 4 & $\begin{array}{l}\text { Socialization of Vision and } \\
\text { Mission }\end{array}$ & 43 & 2 & Fair \\
\hline 5 & The Annual Work Plan & 80 & 3,4 & Good \\
\hline 6 & Five-Year Work Plan & 65 & 3 & Good \\
\hline$\quad$ & Average & $80,3 \%$ & 3,1 & Good \\
\hline
\end{tabular}

It can be concluded that in the planning aspect the PAUD institution on average has a planning document consisting of a vision, mission, objectives, annual work program and five-year work program so that it can be concluded that the PAUD planning documents in West Kalimantan that apply for accreditation in 2017 can categorize as good.

2. Evaluation of Management Standards in Organizing Aspects

The evaluation conducted on the organizing aspect consists of 2 indicators in accordance with the standards in PAUD accreditation, namely:

\section{a. Organizational structure}

To achieve a standard organizational structure that is owned by PAUD institutions must have four elements, namely: (1) Personnel, (2) Personnel Position, (3) Responsibility Flow and (4) Personal Identity. The highest organizational structure owned by PAUD institutions in West
Kalimantan is in the sub-indicators of personnel and personal identities of $95 \%$. While the lowest percentage of the acquisition was in the indicator sub-channel of responsibility, which was $78 \%$.

b. Partnership Network

To achieve a standard partnership network that is owned by PAUD institutions must have four elements, namely: (1) formal, (2) mutual benefit, (3) relevant and (4) sustainable. The PAUD institution's partnership network in West Kalimantan with the highest percentage of its percentage is in the formal sub-indicator, which is $56 \%$. Whereas the lowest percentage of the acquisition is in the sustainable sub-indicator which is $41 \%$.

From all the results of the research on sub-indicators of organizational aspects, the researcher formulates these results in the form of percentages grouped in scores according to the document analysis technique. The results of document analysis have obtained the following results:

Table II

Recapitulation of Documents Accreditation Evaluation on Aspects of Organizing

Management Standards for PAUD in West Kalimantan 2017 Institutions

\begin{tabular}{ccccc}
\hline No & Indicator & $\begin{array}{c}\text { Document } \\
\text { Availability } \\
(\%)\end{array}$ & $\begin{array}{c}\text { Average } \\
\text { Assessment } \\
\text { Results }\end{array}$ & $\begin{array}{c}\text { Assessment } \\
\text { Category }\end{array}$ \\
\hline 1 & Organizational Structure & 100 & 3,7 & Very Good \\
\hline 2 & Partnership Network & 85 & 3,4 & Good \\
\hline & Average & $92,5 \%$ & 3,6 & Very Good \\
\hline
\end{tabular}

The aspect of organizing PAUD institutions is more dominant in having organizing documents consisting of organizational structures and partnership networks so that it can be concluded that the documents of organizing PAUD institutions in West Kalimantan that apply for accreditation in 2017 can be categorized very well.

3. Evaluation of Management Standards on Implementation Aspects

The evaluation carried out on the implementation aspect consists of 3 indicators in accordance with the standards in PAUD accreditation, namely:

a. Implementation Guide

To achieve the standard implementation guidelines owned by PAUD institutions must have 5 types of guidebooks, namely: (1) Guide to Learning Implementation, (2) Guide to Curriculum Development, (3) Guide to the Use of Facilities and Infrastructure (4) Administrative Guidelines and administration and (5) Program Guidelines for parents. The highest implementation guide for PAUD institutions in West Kalimantan is the sub-indicators that guide curriculum development, which is $92 \%$. While the lowest percentage of acquisition was in the sub- 
indicator parental program guide, which was $63 \%$.

b. Administration

In order to achieve standard administration owned by PAUD institutions must have five types of administrative books, namely: (1) Child-Parent Books, (2) Cash Books, (3) Outgoing Books and Incoming Letters (4) Goods Inventory Books, and (5) Guest Book. The highest administration of PAUD institutions in West Kalimantan is the guestbook sub-indicator, which is $92 \%$. While the lowest percentage of the acquisition was in the incoming/outgoing book sub-index, which was $63 \%$.

c. Management Information System

To achieve a standard management information system owned by PAUD institutions must have 11 elements, namely: (1) notice board, (2) brochures / leaflets, (3) unit manuals (4) dissemination of information through print media (5) dissemination of information through electronic media, (6) student data management, (7) teacher data management, (8) student registration, (9) spp money recording, (10) receipt printing and (11) appraisal management. The highest management information system owned by PAUD institutions in West Kalimantan is the sub-indicator of the evaporation board, which is $84 \%$. Whereas the lowest percentage of the acquisition was in the book sub-category of information dissemination through electronic media, namely $30 \%$.

From all the results of the research on sub-indicators of implementation aspects, the researcher formulates these results in the form of percentages grouped in scores according to the document analysis techniques. The results of document analysis have obtained the following results:

Table III

Recapitulation of Accreditation Documents

Evaluation on Aspects of Implementation of The Standard Management of PAUD in West Kalimantan 2017

\begin{tabular}{clccc}
\hline No & \multicolumn{1}{c}{ Indicator } & $\begin{array}{c}\text { Document } \\
\text { Availability } \\
(\%)\end{array}$ & $\begin{array}{c}\text { Average } \\
\text { Assessment } \\
\text { Results }\end{array}$ & $\begin{array}{c}\text { Assessment } \\
\text { Category }\end{array}$ \\
\hline 1 & Implementation Guide & 77,2 & 3,2 & Very Good \\
\hline 2 & Administration & 79,8 & 3 & Good \\
\hline 3 & $\begin{array}{l}\text { Management Information } \\
\text { System (SIM) }\end{array}$ & 61,4 & 2,8 & Fair \\
\hline \multicolumn{2}{c}{ Average } & $72,8 \%$ & 3 & Good \\
\hline & It can be concluded that in the
\end{tabular}
implementation aspect of PAUD institutions, it is more dominant to have documents on implementation which consist of implementation guidelines, administration, and management information systems (SIM). So it can be concluded that the documents on aspects of PAUD implementation in West Kalimantan that apply for accreditation in 2017 can be categorized as good.

4. Evaluation of Management Standards on Supervision Aspects

Evaluation conducted on the supervision aspect consists of 2 indicators in accordance with the standards in PAUD accreditation, namely:

a. Scheduling

To achieve the implementation of standard supervision owned by PAUD institutions must have three elements of supervision period, namely: (1) once a year, (2) twice in 1 year and (3) three times in 1 year. It can be seen that the highest implementation guidelines of PAUD institutions in West Kalimantan are in the onetime sub-indicator of $92 \%$. While the lowest percentage of the acquisition is in the subindicators three times in 1 year, which is $22 \%$. b. Reporting

To achieve standard reporting practices owned by PAUD institutions must have four elements of type supervision, namely: (1) problems found, (2) causes of problems (3) solutions to problems and (4) follow-up of the results of the solutions provided. The highest implementation guide for PAUD institutions in West Kalimantan is the sub-indicator of problems found, which is $23 \%$. While the lowest percentage of the acquisition is in the follow-up subindicators of the solution, which is $5 \%$.

From all the results of the research on sub-indicators of implementation aspects, the researcher formulates these results in the form of percentages grouped in scores according to the document analysis techniques. The results of document analysis have obtained the following results:

Table IV

Recapitulation of Accreditation Documents Evaluation on Aspects of Supervision of The Management Standards of PAUD in West Kalimantan 2017 Institutions

\begin{tabular}{ccccc} 
No & Indicator & $\begin{array}{c}\text { Document } \\
\text { Availability } \\
(\%)\end{array}$ & $\begin{array}{c}\text { Average } \\
\text { Assessment } \\
\text { Results }\end{array}$ & $\begin{array}{c}\text { Assessment } \\
\text { Category }\end{array}$ \\
\hline 1 & Scheduling & 25,33 & 2,7 & Very Good \\
\hline 2 & Reporting & 12 & 2,2 & Good \\
\hline & Average & $18,5 \%$ & 2,4 & Fair \\
\hline
\end{tabular}

It can be concluded that in the aspect of organizing PAUD institutions it is more dominant not to have an organizing document consisting of organizational structure and partnership network so that it can be concluded that the documents of organizing PAUD institutions in West Kalimantan that apply for accreditation in 2017 can be categorized as not good.

5. Evaluation of Management Standards on Aspects of Assessment of work 
Evaluation conducted on the supervision aspect consists of 3 indicators in accordance with the standards in PAUD accreditation, namely:

a. Assessment Elements

To achieve the implementation of the standard assessment elements possessed by PAUD institutions must have 5 elements of assessment, namely: (1) conformity of vision, mission and goals, (2) conformity with the work plan, (3) conformity with the target, (4) timeliness and (5) accuracy in solving problems. The highest implementation guide for PAUD institutions in West Kalimantan is the sub-indicator of timeliness, which is $19 \%$. While the lowest percentage of the acquisition is in the subindicator of the suitability of the vision, mission, and goals, which is $10 \%$.

b. Documentation

To achieve a standardized performance appraisal that is owned by PAUD institutions must have four assessment elements, namely: (1) reports analyzed and reported, (2) reports analyzed but not reported, (3) reports not analyzed but reported and (4) reports available but not analyzed and not reported. The highest implementation guide for PAUD institutions in West Kalimantan is the report sub-indicators, but not analyzed and not reported as much as $12 \%$. While the lowest percentage of the acquisition is in the report sub-indicators analyzed and reported, the mission and objectives are $5 \%$.

c. Appreciation

To achieve the standard type of award that is owned by PAUD institutions must have four elements of assessment, namely: (1) local, (2) province, (3) national and (4) international.

The highest implementation guide for PAUD institutions in West Kalimantan is the report sub-indicators, but not analyzed and not reported as much as $12 \%$. While the lowest percentage of the acquisition is in the report subindicators analyzed and reported, the mission and objectives are $5 \%$.

From all the results of the research on sub-indicators of implementation aspects, the researcher formulates these results in the form of percentages grouped in scores according to the document analysis techniques. The results of document analysis have obtained the following results:
Table V

Recapitulation of Accreditation Documents

Evaluation on Aspects Of Work Evaluation of The Management Standards of PAUD Institutions in West Kalimantan 2017

\begin{tabular}{llccc}
\hline No & \multicolumn{1}{c}{ Indicator } & $\begin{array}{c}\text { Document } \\
\text { Availability } \\
(\%)\end{array}$ & $\begin{array}{c}\text { Average } \\
\text { Assessment } \\
\text { Results }\end{array}$ & $\begin{array}{c}\text { Assessment } \\
\text { Category }\end{array}$ \\
\hline 1 & Assessment Elements & 8,3 & 2,3 & Very Good \\
\hline 2 & Documentation & 8,9 & 2 & Good \\
\hline 3 & Appreciation & 34,3 & 2,8 & Good \\
\hline & Average & 17,3 & 2,3 & Fair \\
\hline
\end{tabular}

The aspect of assessment of the work of PAUD institutions is more dominant in not having a document on assessment of work which consists of elements of assessment, documentation, and awards. So it can be concluded that the assessment documents on the work of PAUD institutions in West Kalimantan that apply for accreditation in 2017 can be categorized quite well.

Based on the research findings from the five aspects above, the researcher concludes the research findings as follows.

Table VI

Recapitulation of Evaluation of Accreditation

Documents on Management Standards PAUD

Unit In West Kalimantan 2017

\begin{tabular}{llccc}
\hline No & $\begin{array}{c}\text { Assessment } \\
\text { Aspects }\end{array}$ & $\begin{array}{c}\text { Document } \\
\text { Availability } \\
(\%)\end{array}$ & $\begin{array}{c}\text { Average Assessment } \\
\text { Results }\end{array}$ & $\begin{array}{c}\text { Assessment } \\
\text { Category }\end{array}$ \\
\hline 1 & Planning & 80,3 & 3,1 & Good \\
\hline 2 & Organizing & 92,5 & 3,6 & Very Good \\
\hline 3 & Implementation & 72,8 & 3 & Good \\
\hline 4 & Supervision & 18,5 & 2,7 & Fair \\
\hline 5 & $\begin{array}{l}\text { Assessment of } \\
\text { Work }\end{array}$ & 17,3 & 2,6 & Fair \\
\hline & \multicolumn{1}{c}{ Average } & 56,28 & 3 & Good \\
\hline
\end{tabular}

Based on the results of research on the five aspects of PAUD management standards, it can be concluded that the PAUD management standards that apply for accreditation in 2017 are categorized as good overall, but if viewed from its aspects, aspects of supervision and assessment are still categorized as good. While the percentage of the highest document ownership achievement is in the organizing aspect that is equal to $92.5 \%$, then the planning aspect is $82.3 \%$ followed by the implementation aspect of $72.8 \%$, and supervision of $17.3 \%$ and the aspect of work evaluation is 18.5 $\%$.

\section{B. Discussion}

The following are findings of research on management standards and supporting theories which consist of 5 aspects:

1. Planning

In the research results, the results of evaluation on planning aspects of PAUD management standards have been categorized as good, meaning that the plans prepared by PAUD institutions that apply for accreditation in 2017 have been prepared by planning 
standards that must be carried out in PAUD institutions. The formulation of the standard vision, mission, and goals of the institution is one of the indicators of strength in planning because these indicators are the basis of PAUD institutions in preparing programs that will be implemented at the institution.

According to Suyadi, (2011: 43), The vision seems to describe the ideals of PAUD institutions that want to be achieved in the long run as an ideal form of institution. While the mission is its form of vision in the form of operational steps or superior strategies to realize the vision of an institution.

The National Accreditation Board determines the standard vision consists of 4 stretches, namely:

a. Short solid

Short of solid means that the maximum content of the vision consists of only 20 words

b. Realistic,

Realistic means according to the conditions and situation of the institution.

c. Visionary

Visionary in the sense that it corresponds to development.

d. Relevant

Relevant in meaning according to real needs.

e. Measured

Measured in the sense that it can be implemented

Whereas for the mission contains four elements, namely:

a. Relevant

Relevant means according to vision.

b. Realistic

Realistic means according to conditions.

c. Consistent

Consistent means that it is carried out according to the vision

d. Measured

Measured in the sense that it can be implemented As for the purpose contains four elements, namely:

a. Consistent with vision

Consistent with vision means the contents of the goal must be derived from the vision that the institution has

b. Consistent with Mission

Consistent with vision means the contents of the goal must be derived from the vision that the institution has

c. Realistic

Realistic means according to the conditions at the current institution

d. Measured

Measured means that goals can be implemented
Based on the results of the study of the document of vision, mission and objectives of PAUD institutions that apply for accreditation in 2017 on average already contain the elements set by the PAUD and PNF BAN standards, the researcher cannot see the implementation in the field towards conformity in implementation. Furthermore, the vision, mission and objectives based on the standards of PAUD and PNF BAN must be disseminated to the public through 4 ways: (1) through print media (brochures, banner flyers etc.), (2) meetings with parents, (3) institutional work meetings , (4) Online media and (5) posted on the announcement board. Based on the results of the research that the PAUD's vision, mission, and objectives are not all the ways done, only a few institutions do the five ways, meaning that some PAUD institutions do not know that the vision, mission, and goals must be socialized.

For the annual work program and the fiveyear work program, documents owned by the institution reach $75 \%$, meaning that the ownership of annual and five-year work plan documents has an average document, but for the substance of the work plan PAUD and PNF BAN make 5 elements that must be in the work plan, namely: (1) goals, (2) targets, (3) policies, (4) programs/activities and (5) financing, not all institutions fulfill these five elements.

In this planning aspect, the researcher believes that PAUD institutions still need an understanding related to the preparation of good planning so that the planning prepared in the draft can be standardized and the implementation of the program is more optimal in accordance with the planning prepared.

\section{Organizing}

In this aspect of organizing consists of 2 indicators, namely the organizational structure and partnership network. A standard organizational structure must meet five elements, namely:

a. Personnel

It means that the organizational structure of the institution must have personnel

b. Personnel Position

It means that the organizational structure must include the personnel position

c. Responsibility Flow

It means that in the organizational structure, the flow of responsibilities must be included

d. Personal Identity

It means that in the organizational structure of PAUD institutions there must be a personal identity.

e. Job Description

It means that the organizational structure of the institution must contain a description of the duties of each of its personnel. 
As for the partnership network BAN PAUD and PNF establishes five criteria for partnership networks, namely:

a. Formal

Official partnership that is accompanied by memorandum of understanding (MOU),

b. Mutual benefits

Partnerships carried out with other parties are mutually beneficial

c. Relevant

Partnerships carried out must be relevant (according to conditions)

d. Sustainability

Partnerships implemented must be sustainable Hadari Nawawi (1992) (in Hariri, 2016: 8) suggested several principles in the organization, including:

1. The organization must be professional, that is by the division of work units in accordance with needs;

2. Grouping of work units must describe the division of labor;

3. The organization must regulate the delegation of authority and responsibility;

4. The organization must reflect the range of controls;

5. The organization must contain unity of orders; and

6. The organization must be flexible and balanced.

Among several principles of organization, the results of the research are in line with the organizing theory carried out in PAUD institutions that apply for accreditation in 2017 in West Kalimantan. Based on the results of research on the aspect of organizing, it is categorized as good, meaning that the organizing documents owned by PAUD institutions that apply for accreditation in 2017 in West Kalimantan are standard with those set by BAN PAUD and PNF.

3. Implementation

Hariri (2016: 9) presents from a whole series of management processes, actuating is the most important management function. The planning and organizing function has more to do with the abstract aspects of the management process, while the implementation function emphasizes activities that are directly related to people in the organization.

In the implementation aspects of PAUD management standards, PAUD and PNF BAN establish three indicators on implementation aspects, namely:

a. Implementation guidelines

PAUD institutions must have five implementation guidelines, namely: (1) guidelines for learning implementation, (2) curriculum development guidelines, (3) guidelines for the use of facilities and infrastructures, (4) administration guidelines and (5) program guides to masters. b. Administration

The administration that must be owned by the institution is: (1) children's parent book, (2) cash book, (3) outgoing and incoming mail book, (4) goods inventory book and (5) guest book.

c. Management information system

The management information system that must be owned by the institution consists of: (1) notice board, (2) brochure, (3) satuaan guidebook, (4) dissemination of information through print media, (5) dissemination of information through electronic media (6) management data of students, (7) management of teacher data, (8) registration of students, (9) recording of tuition fees, (10) printing of receipts and (11) management of assessments.

Based on the results of the research implementation aspects are categorized as good, meaning that documents related to the implementation aspects owned by the majority institution are in accordance with the standards set by BAN PAUD and PNF.

4. Supervision

In government regulation no. 19 of 2007 The Supervision Process Includes (1) monitoring, (2) supervision, (3) evaluation, (4) reporting, and followup to the results of supervision. BAN PAUD and PNF stipulate that the supervision process consists of 2 indicators, namely:

a. Scheduling

Scheduling a standard supervision process is carried out periodically at least once a year.

b. Reporting

Reporting on the results of the results must contain four elements of analysis, namely: (1) problems found, (2) causes of problems, (3) solutions to problems and (4) follow-up solutions provided.

T. Hani Handoko $(2009 ; 26)$ proposes five stages of supervision, namely "(1) setting standards for implementation (planning), (2) determining the measurement of activities, (3) measuring the implementation of real activities, (4) comparing the implementation of activities with standards and analyzing irregularities, and (5) taking corrective action if necessary ".

Based on the results of the study, the aspect of supervision is categorized as good enough. The meaning is that the supervision program carried out or the documents held about the supervision of PAUD institutions on average are still not maximally available and the elements of supervision are not yet achieving good standards.

5. Assessment of Work

Assessment of work results in PAUD management standards consists of elements of assessment, documentation of assessments and awards. The elements of assessment include five aspects, namely: (1) conformity with the vision, 
mission and objectives, (2) conformity with the work plan, (3) timeliness and (4) accuracy in problemsolving. Of the five aspects, the average institution has not yet implemented. While for documentation assessment there are four elements, namely: (1) reports are analyzed and reported, (2) reports are analyzed but not reported, (3) reports not analyzed remain unreported and (4) Reports exist but not analyzed and not reported.

\section{CONCLUSIONS AND SUGGESTIONS}

\section{A. Conclusions}

Based on the results of the study and discussion of the evaluation of PAUD management standards in 2017, the researchers concluded that the findings of the study were based on the formulation of the problems discussed in this study, namely:

1. Planning Aspects

The planning document which consists of the vision, mission, objectives, annual work plan and the average five-year work plan owned by the institution with a percentage of $80.3 \%$. Based on document analysis criteria, it is classified as good with an average score of 3.1. By standardization based on the rubric of accreditation of BAN PAUD and PNF BAN, score 3 is the criteria for available and complete documents but not yet according to the rubric.

2. Organizing aspect

Organizing documents consisting of organizational structure, job descriptions, and partnerships, the average owned by the institution with a percentage of $92.5 \%$. If based on document analysis criteria it is very good with an average score of 3.6. By standardization, based on the assessment rubric of PAAN and PNF BAN accreditation, score 3 is the criteria for available and complete documents, but not according to the rubric.

3. Implementation aspects

The implementation document, which consists of implementation guidelines, administration, and management information systems, on average is owned by institutions with a percentage of $72.8 \%$. If based on the document analysis criteria it is classified as good with an average score of 3. Regarding standardization based on the assessment rubric of PAAN and PNF accreditation BAN score 3 is the criteria for available and complete documents but not in accordance with the rubric.

4. Supervision aspect

The planning document which consists of scheduling supervision and reporting of the average supervision is not yet owned by the institution with a total of $18.5 \%$ of processing. Based on document analysis criteria is quite good with an average score of 2.4. By standardization, based on the assessment rubric of PAAN and PNF BAN accreditation, score 2 is a document available criteria but has not fulfilled the completeness and suitability based on the rubric.

\section{Aspect assessment of work}

Planning documents consisting of elements of assessment, documentation, and awards on average not yet owned by the institution with a total of $17.3 \%$ of the amount of processing. Based on document analysis criteria, it is classified as good with an average score of 2.4. By standardization, based on the assessment rubric of PAAN and PNF BAN accreditation, score 2 is a document available criteria but has not fulfilled the completeness and suitability based on the rubric.

6. Management standards

Based on the evaluation recapitulation of all aspects of the management standards that PAUD institutions on average do not yet have a work inspection and assessment document therefore it is a problem that the low percentage achievement of 8 standards in PAUD units that apply for accreditation in 2017 due to the low 2 aspects PAUD institutions have not yet been launched.

B. Suggestions

1. To PAUD Institution Managers

a. Documents on planning aspects related to the vision, mission, objectives, annual work plan and annual work plan of the LLA are compiled according to the standards of BUD PAUD and PNF.

b. Documents on the aspect of organizing which one of the indicators is found on the institution's partnership network documents with other parties need to be well documented, starting from the cooperation letter, substance of the letter and photos of the implementation.

c. Documents on the implementation aspects which one of them has an indicator about the management information system (SIM) in which 11 items in the SIM must be owned by the institution, it is necessary to conduct a work meeting on the preparation of SIM.

d. Documents on the supervision aspect need to be carried out periodic preparation and implementation of supervision by the institution and formulate a supervision model format that is in accordance with the standards of PAUD and PNF BAN

e. Assessment documents for the institution's work need to be made in the form of an assessment format and its implementation, especially for the Play Group service program so that the institution can evaluate the implementation of work at least once a year.

2. Chair and Members of the West Kalimantan BUD PAUD and PNF

a. Providing continuous technical guidance related to 8 national education standards, especially in PAUD institutions.

b. Coordinating with the District / City education and culture related to accreditation socialization 
so that the institution can prepare documents related to accreditation.

c. District / City Education and Culture Office in West Kalimantan.

d. Providing regular guidance and guidance to PAUD institutions regarding institutional management so that they can carry out all indicators in their particular management standards on aspects of supervision and assessment of work.

e. Guiding PAUD supervisors or supervisors to conduct periodic monitoring to assisted institutions and supervisors to provide an example to the institution to do the same to teachers and administrators.

\section{REFERENCES}

Daniel, L. Stuffbleam \& Chris, L.S Coryn. 2014. Evaluation Theory, Models and Application. Unites States of Amerika: HB printing.

Handoko, T. Hani. 2009. Manajemen. Yogyakarta: BPFE-Yogyakarta.

Hariri, Hasan, et al. 2016. Manajemen Pendidikan, Yogjakarta; Media Akademi

Kemendikbud. 2014. Peraturan Mentri Pendidikan dan Kebudayaan No.137 Tahun 2014 Tentang Standar Nasional Pendidikan Anak Usia Dini, Jakarta.

Peraturan Pemerintah Republik Indonesia Nomor 19 Tahun 2005 tentang Standar nasional pendidikan.

Peraturan Pemerintah Republik Indonesia Nomor 13 Tahun 2015 tentang Standar nasional pendidikan.

Suyadi. 2011. Manajemen PAUD. Pustaka Pelajar, Yogyakarta.

Wirawan, 2011. Evaluasi Teori, Model Standar, Aplikasi dan Profesi. Jakarta: PT.Rajagrafindo Persada. 